\title{
HUBUNGAN ANTARA BEBAN KERJA, STRES KERJA DAN TINGKAT KONFLIK DENGAN KELELAHAN KERJA PERAWAT DI RUMAH SAKIT ISLAM YOGYAKARTA PDHI KOTA YOGYAKARTA
}

\author{
Widodo Hariyono, Dyah Suryani, Yanuk Wulandari \\ Fakultas Kesehatan Masyarakat, Universitas Ahmad Dahlan, Yogyakarta
}

\begin{abstract}
Background : Hospital are organizations that are running health service to the society in certain area of coverage. In giving its service, there is residential service that dominates the services available. It's because the service giving such contribution for patient care. According to the medical record RSIY PDHI in the current 2 months the residential service experiences increase of patient number, about 10 percent. Thus however causes the service burden increased and if it's continuing may causing fatigue that decreases the services quality. A lot of work may give trouble and stress to the nurses. This research's goal is to figure out relation between burden or work, jon stress, and the level of conflict to nurse's exhaustion in RSIY PDHI.

Methods : This research was a quantitative research using analytical survey method (explanatory study) with cross sectional plan of research. Samples are nurses of residential service, 52 persons in number. This research utilizes questionnaire and data analysis with chi-square equation $(\rho=0.05)$.

Results : This research showed there are strong relationship between burden of work, job stress, and the level of conflict to nurse's exhaustion among the nurses with level of significance burden of work $(\rho=0.000)$, job stress $(\rho=0.026)$, and the level of conflict $(\rho=0.000)$.

Conclusion : Any relation between burden of work with nurse's exhaustion in residential service. Any relation between job stress with nurse's exhaustion and any relation between the level of conflict with nurse's exhaustion. That's way it's needed to develop the nurse's career, well stress management, and conflict optimizing that the nurses would be kept motivated in working that it would tackle nurse's exhaustion.
\end{abstract}

Keywords: Burden of Work, Job Stress, The Level of Conflict, and Nurse's Exhaustion

\section{PENDAHULUAN}

Rumah sakit merupakan salah satu organisasi yang bergerak di bidang kesehatan untuk memenuhi kebutuhan pelayanan kesehatan masyarakat di suatu wilayah. Sebuah Rumah Sakit akan memberikan pelayanan optimal manakala didukung oleh sumber daya yang berkualitas. Sumber daya yang dibutuhkan Rumah Sakit pun sangat beragam, salah satunya adalah sumber daya manusia. Sumber daya manusia merupakan unsur penting karena bersifat jasa dan tidak dapat disimpan sebagai persediaan, tetapi hanya diproduksi pada saat dikonsumsi karena sumber daya manusia merupakan aset utama dalam memberikan tenaga, potensi, kreativitas, dan usaha terhadap kemajuan Rumah Sakit tersebut.

Rumah Sakit sebagai salah satu fasilitas pelayanan kesehatan memiliki peran yang sangat strategis dalam menciptakan sumber daya manusia berkualitas sebagai upaya mempercepat peningkatan derajat kesehatan secara menyeluruh, merata, terjangkau dan dapat diterima oleh seluruh masyarakat. Peran strategis ini didapat karena Rumah Sakit adalah fasilitas pelayanan kesehatan yang padat teknologi, modal, karya dan pakar. Dewasa ini peran tersebut semakin menonjol mengingat munculnya perubahan - perubahan epidemiologi penyakit, struktur demografis, perkembangan IPTEK, struktur sosio - ekonomi masyarakat, yang menuntut pelayanan yang lebih bermutu, ramah dan sanggup memenuhi harapan, keinginan, dan kebutuhan mereka. Tuntutan tersebut akan bertambah berat dalam menghadapi era 
sekarang yang perubahannya sangat cepat, apabila tidak diikuti dengan keberadaan SDM Rumah Sakit yang profesional dan bermutu tinggi. Dampak dari perubahan itu akan mendorong organisasi Rumah Sakit sehingga membutuhkan pengelolaan atau konsep manajemen yang tepat. ${ }^{1}$

Dalam penyelenggaraan upaya pelayanan kesehatan, pelayanan di instalasi rawat inap merupakan bagian pelayanan kesehatan yang cukup dominan. Karena pelayanan instalasi rawat inap merupakan pelayanan yang sangat kompleks dan memberikan kontribusi yang paling besar bagi kesembuhan pasien rawat inap. Peranan seorang perawat saat melayani pasien di rawat inap (opname) sangatlah berpengaruh terhadap kesembuhan pasien tersebut. Sehingga, dapat dikatakan bahwa perawat merupakan ujung tombak pelayanan Rumah Sakit karena selalu berinteraksi secara langsung dengan pasien, keluarga pasien, dokter dan tenaga kerja lainnya. Perawat mempunyai tanggung jawab yang cukup besar dan dituntut bekerja secara profesional dalam memberikan pelayanan terhadap pasien. ${ }^{1}$

Perkembangan tenaga perawat menjadi profesi telah disepakati pada Lokakarya Nasional Keperawatan tahun 1983, dengan definisi bahwa keperawatan berbentuk pelayanan bio - psiko - sosial - spiritual yang komprehensif, dimana tugas dan tanggung jawab perawat serta peran perawat dalam memberikan pelayanan cukup menunjang kesembuhan pasien. Pelayanan ini ditujukan kepada individu, keluarga, dan masyarakat baik yang sakit maupun sehat mencakup seluruh proses kehidupan manusia.

Berdasarkan studi pendahuluan yang dilakukan pada hari Rabu, tanggal 29 Juli 2009, di Rumah Sakit Islam Yogyakarta PDHI selama dalam kurun waktu 2 bulan terakhir ini mengalami kenaikan jumlah pasien yang cukup signifikan baik di rawat inap maupun rawat jalan. Berdasarkan laporan dan wawancara dengan bagian rekam medis, Ibu Eni mengatakan bahwa "apabila dibandingkan dengan jumlah kunjungan pasien beberapa bulan yang lalu, maka dalam 2 bulan terakhir ini tercatat kenaikan pasien meningkat hingga $10 \%$. Hal ini kemungkinan akan terus meningkat hingga akhir tahun". Hasil wawancara pada hari yang sama dengan Kepala Rekam Medis menyatakan naiknya jumlah pasien membuat beban kerja perawat menjadi berlebihan sehingga apabila hal ini berkelanjutan akan menyebabkan kelelahan yang berujung pada penurunan kualitas pelayanan. Sementara wawancara dengan Kepala ruang bangsal Ismail mengatakan adanya tuntutan pekerjaan yang mendesak juga dapat memicu konflik dan stres pada perawat seperti dialami oleh beberapa perawat di bangsal Ismail dan Arofah. Bangsal Ismail adalah ruangan khusus anak, namun bila pasien dewasa yang seharusnya dirawat di ruang Arofah meningkat, maka pasien tersebut akan dititipkan ke bangsal Ismail. Hal ini tentu akan berimbas pada meningkatnya beban kerja perawat di bangsal Ismail.

Bertolak dari uraian di atas, peneliti tertarik untuk melihat lebih lanjut beberapa penyebab kelelahan kerja yang sering terjadi pada perawat pelaksana instalasi rawat inap di Rumah Sakit Islam Yogyakarta PDHI, maka peneliti mengadakan penelitian dengan judul Hubungan antara Beban Kerja, Stres Kerja dan Tingkat Konflik dengan Kelelahan Kerja Perawat di Rumah Sakit Islam Yogyakarta PDHI Kota Yogyakarta.

\section{METODE PENELITIAN}

Penelitian ini merupakan penelitian kuantitatif dengan metode penelitian survey (survey research method) yang bersifat analitik (explanatory study) dengan menggunakan rancangan penelitian cross sectional. Dalam penelitian ini, variabel sebab (independent variable) dan variabel akibat (dependent variable) yang terjadi pada objek penelitian diukur atau dikumpulkan dalam waktu yang bersamaan. ${ }^{2}$ 
Populasi dalam penelitian ini adalah seluruh perawat di instalasi rawat inap Rumah Sakit PDHI berjumlah 52 perawat. Teknik pengambilan sampel menggunakan teknik sampel jenuh atau sering disebut total sampling yaitu seluruh populasi dalam penelitian. ${ }^{3}$

Data dianalisis secara univariat dan bivariat. Analisis univariat digunakan untuk mengetahui distribusi frekuensi responden seperti umur, jenis kelamin dan status perkawinan responden. Analisis bivariat menggunakan analisis chi-square yaitu untuk mencari hubungan dan menguji hipotesis antara dua variabel bila datanya berbentuk nominal maupun ordinal. ${ }^{4}$

\section{HASIL PENELITIAN DAN PEMBAHASAN}

\section{a. Karakteristik Responden}

Penelitian dilakukan di Rumah Sakit Islam Yogyakarta PDHI pada bulan Agustus hingga September 2009. Subjek penelitian adalah perawat di Instalasi Rawat Inap RSIY PDHI pada bangsal Halimah, Ismail, Ruhama, dan Arofah yang berjumlah 52 perawat tetap. Berikut adalah karakteristik responden berdasarkan jenis kelamin, umur, dan status perkawinan yang dijelaskan dalam bentuk tabel.

1). Jenis Kelamin

Tabel 1. Distribusi Responden Berdasarkan Jenis Kelamin di Rumah Sakit Islam Yogyakarta PDHI Tahun 2009

\begin{tabular}{llcc}
\hline No. & Jenis Kelamin & Frekuensi & Persentase (\%) \\
\hline 1. & Laki - laki & 2 & 3,8 \\
\hline 2. & Perempuan & 50 & 96,2 \\
\hline & Total & 52 & 100 \\
\hline
\end{tabular}

Berdasarkan tabel di atas, dapat diketahui bahwa sebagian besar responden mempunyai jenis kelamin perempuan dengan jumlah 50 perawat $(96,2 \%)$.

2). Umur

Tabel 2. Distribusi Responden Berdasarkan Umur di Rumah Sakit Islam Yogyakarta PDHI Tahun 2009

\begin{tabular}{|c|c|c|c|}
\hline No. & Umur & Frekuensi & Persentase (\%) \\
\hline 1. & $20-30$ & 46 & 88,5 \\
\hline 2. & $31-40$ & 6 & 11,5 \\
\hline & Total & 52 & 100 \\
\hline
\end{tabular}

Berdasarkan tabel di atas, dapat diketahui bahwa sebagian besar responden mempunyai umur antara $20-30$ tahun sebesar 46 perawat $(88,5 \%)$. 
3). Status Perkawinan

Tabel 3. Distribusi Responden Berdasarkan Status Perkawinan di Rumah Sakit Islam Yogyakarta PDHI Tahun 2009

\begin{tabular}{llcc}
\hline No. & \multicolumn{1}{c}{ Status Perkawinan } & Frekuensi & Persentase (\%) \\
\hline 1. & Kawin & 29 & 55,8 \\
\hline 2. & Belum kawin & 23 & 44,2 \\
\hline & Total & 52 & 100 \\
\hline
\end{tabular}

Berdasarkan tabel di atas, dapat diketahui bahwa dari 52 responden sebagian besar sudah menikah yaitu berjumlah 29 perawat $(55,8 \%)$.

\section{a. Analisis Univariat}

Analisis univariat dilakukan untuk mengetahui deskripsi kelelahan kerja, beban kerja, stres kerja, dan tingkat konflik.

1). Kelelahan Kerja

Tabel 4. Distribusi Kelelahan Kerja Perawat di Rumah Sakit Islam

\begin{tabular}{llcc}
\multicolumn{1}{l}{\begin{tabular}{l} 
Yogyakarta PDHI Tahun 2009 \\
\hline No.
\end{tabular}} & \multicolumn{1}{c}{ Keterangan } & Frekuensi & Persentase (\%) \\
\hline 1. & Sangat lelah & 3 & 5,77 \\
\hline 2. & Lelah & 29 & 55,77 \\
\hline 3. & Agak lelah & 19 & 36,54 \\
\hline 4. & Tidak lelah & 1 & 1,92 \\
\hline & Total & 52 & 100 \\
\hline
\end{tabular}

Berdasarkan tabel di atas, maka dapat disimpulkan bahwa sebagian besar perawat merasa lelah dengan frekuensi 29 perawat $(55,77 \%)$.

2). Beban Kerja

Tabel 5. Distribusi Beban Kerja Perawat di Rumah Sakit Islam Yogyakarta PDHI Tahun 2009

\begin{tabular}{llcc}
\hline No. & \multicolumn{1}{c}{ Keterangan } & Frekuensi & Persentase (\%) \\
\hline 1. & Rendah & 5 & 9,61 \\
\hline 2. & Sedang & 32 & 61,54 \\
\hline 3. & Tinggi & 15 & 28,85 \\
\hline & Total & 52 & 100 \\
\hline
\end{tabular}

Berdasarkan tabel di atas, maka dapat disimpulkan bahwa $61,54 \%$ perawat mempunyai beban kerja yang sedang, dengan frekuensi 32 responden.

\section{3). Stres Kerja}

Tabel 6. Distribusi Stres Kerja Perawat di Rumah Sakit Islam Yogyakarta PDHI Tahun 2009

\begin{tabular}{llcc}
\hline No. & \multicolumn{1}{c}{ Keterangan } & Frekuensi & Persentase (\%) \\
\hline 1. & Rendah & 1 & 1,92 \\
\hline 2. & Sedang & 43 & 82,70 \\
\hline 3. & Tinggi & 8 & 15,38 \\
\hline & Total & 52 & 100 \\
\hline
\end{tabular}


Berdasarkan tabel di atas, maka dapat disimpulkan bahwa $82,70 \%$ perawat mempunyai stres kerja yang sedang, dengan frekuensi 43 responden.

4). Tingkat Konflik

Tabel 7. Distribusi Tingkat Konflik Perawat di Rumah Sakit Islam Yogyakarta PDHI Tahun 2009

\begin{tabular}{clcc}
\hline No. & Keterangan & Frekuensi & Persentase (\%) \\
\hline 1. & Rendah & 2 & 3,85 \\
\hline 2. & Sedang & 35 & 67,30 \\
\hline 3. & Tinggi & 15 & 28,85 \\
\hline & Total & 52 & 100 \\
\hline
\end{tabular}

Berdasarkan tabel di atas, maka dapat disimpulkan bahwa $82,70 \%$ perawat mempunyai tingkat konflik yang sedang, dengan frekuensi 35 responden.

\section{b. Analisis Bivariat}

1). Hubungan Beban Kerja dengan Kelelahan Kerja Perawat

Tabel 8. Hubungan antara Beban Kerja dengan Kelelahan Kerja Perawat di Rumah Sakit Islam Yogyakarta PDHI Tahun 2009

\begin{tabular}{|c|c|c|c|c|c|c|c|c|c|c|}
\hline \multirow{3}{*}{ Beban Kerja } & \multicolumn{8}{|c|}{ Kelelahan Kerja } & \multicolumn{2}{|c|}{ Total } \\
\hline & \multicolumn{2}{|c|}{ Tidak lelah } & \multicolumn{2}{|c|}{ Agak lelah } & \multicolumn{2}{|c|}{ Lelah } & \multicolumn{2}{|c|}{ Sangat lelah } & \multirow[t]{2}{*}{$\mathrm{n}$} & \multirow[t]{2}{*}{$\%$} \\
\hline & $\mathrm{N}$ & $\%$ & $\mathrm{n}$ & $\%$ & $\mathrm{n}$ & $\%$ & $\mathrm{~N}$ & $\%$ & & \\
\hline Rendah & 1 & 1,9 & 4 & 7,7 & 0 & 0 & 0 & 0 & 5 & 9,6 \\
\hline Sedang & 0 & 0 & 7 & 13,5 & 24 & 46,2 & 0 & 0 & 31 & 59,6 \\
\hline Tinggi & 0 & 0 & 8 & 15,4 & 5 & 9,6 & 3 & 5,8 & 16 & 30,8 \\
\hline Total & 1 & 1,9 & 19 & 36,5 & 29 & 55,8 & 3 & 5,8 & 52 & 100 \\
\hline
\end{tabular}

Berdasarkan tabel di atas, dapat diketahui bahwa 29 orang perawat merasa lelah $(55,8 \%)$ dan 31 perawat mempunyai beban kerja sedang $(59,6 \%)$.

2). Hubungan antara Stres Kerja dengan Kelelahan Kerja Perawat

Tabel 9. Hubungan antara Stres Kerja dengan Kelelahan Kerja Perawat di Rumah Sakit Islam Yogyakarta PDHI Tahun 2009

\begin{tabular}{|c|c|c|c|c|c|c|c|c|c|c|}
\hline \multirow{3}{*}{ Stres Kerja } & \multicolumn{8}{|c|}{ Kelelahan Kerja Total } & \multirow{2}{*}{\multicolumn{2}{|c|}{ Total }} \\
\hline & \multicolumn{2}{|c|}{ Tidak lelah } & \multicolumn{2}{|c|}{ Agak lelah } & \multicolumn{2}{|c|}{ Lelah } & \multicolumn{2}{|c|}{ Sangat lelah } & & \\
\hline & $\mathrm{n}$ & $\%$ & $\mathrm{n}$ & $\%$ & $\mathrm{n}$ & $\%$ & $\mathrm{n}$ & $\%$ & $\mathrm{n}$ & $\%$ \\
\hline Rendah & 1 & 1,9 & 2 & 7,7 & 2 & 0 & 0 & 0 & 5 & 9,6 \\
\hline Sedang & 0 & 0 & 14 & 13,5 & 22 & 46,2 & 1 & 0 & 37 & 71,2 \\
\hline Tinggi & 0 & 0 & 3 & 15,4 & 5 & 9,6 & 2 & 5,80 & 10 & 19,2 \\
\hline Total & 1 & 1,9 & 19 & 36,5 & 29 & 55,8 & 3 & 5,80 & 52 & 100 \\
\hline
\end{tabular}


Berdasarkan tabel di atas, dapat diketahui bahwa 29 orang perawat merasa lelah $(55,8 \%)$, Selain itu, tabel di atas juga menunjukkan 37 perawat mempunyai stres kerja sedang $(71,2 \%)$.

3). Hubungan antara Tingkat Konflik dengan Kelelahan Kerja Perawat

Tabel 10. Hubungan antara Tingkat Konflik dengan Kelelahan Kerja Perawat di Rumah Sakit Islam Yogyakarta PDHI Tahun 2009

\begin{tabular}{lcccccccccc}
\hline Tingkat Konflik & \multicolumn{1}{c}{ Kelelahan Kerja } \\
& \multicolumn{2}{c}{ Tidak lelah } & \multicolumn{2}{c}{ Agak lelah } & \multicolumn{2}{c}{ Lelah } & \multicolumn{2}{c}{ Sangat lelah } \\
& $\mathrm{n}$ & $\%$ & $\mathrm{n}$ & $\%$ & $\mathrm{n}$ & $\%$ & $\mathrm{n}$ & $\%$ & $\mathrm{n}$ & $\%$ \\
\hline Rendah & 1 & 1,9 & 0 & 7,7 & 1 & 0 & 0 & 0 & 2 & 3,8 \\
\hline Sedang & 0 & 0 & 13 & 13,5 & 19 & 46,2 & 2 & 0 & 24 & 65,4 \\
\hline Tinggi & 0 & 0 & 6 & 15,4 & 9 & 9,6 & 1 & 5,80 & 16 & 30,8 \\
\hline Total & 1 & 1,9 & 19 & 36,5 & 29 & 55,8 & 3 & 5,80 & 52 & 100 \\
\hline
\end{tabular}

Berdasarkan tabel di atas, dapat diketahui bahwa 29 orang perawat merasálelah $(55,8 \%)$ dan 24 perawat mempunyai tingkat konflik sedang $(65,4 \%)$.

4). Hubungan antara Beban Kerja, Stres Kerja dan Tingkat Konflik dengan Kelelahan Kerja Perawat di RSIY PDHI

$\begin{aligned} & \text { Tabel 11. Hasil Uji Chi-Square Hubungan antara Beban Kerja, Stres Kerja dan Tingkat Konflik } \\
& \text { dengan Kelelahan Kerja Perawat di Rumah Sakit Islam Yogyakarta PDHI Tahun 2009 }\end{aligned}$
\begin{tabular}{lcccccc} 
Variabel & $\begin{array}{c}\text { Chi-Square } \\
\text { hitung }\end{array}$ & df & $\begin{array}{c}\text { Chi-Square } \\
\text { tabel }\end{array}$ & Sig. ñ & Keterangan \\
\hline Beban Kerja & 28,300 & 6 & 12,592 & 0,000 & Ada hubungan \\
\hline Stres Kerja & 14,325 & 6 & 12,592 & 0,026 & Ada hubungan \\
\hline Tingkat Konflik & 25,897 & 6 & 12,592 & 0,000 & Ada hubungan \\
\hline
\end{tabular}

Berdasarkan tabel di atas, dengan ketentuan apabila nilai taraf signifikansi $<0,05$ maka hipotesis diterima dan apabila nilai taraf signifikansi $>0,05$ maka hipotesis ditolak. Atau berdasarkan nilai chi-square tabel < chisquare hitung maka hipotesis diterima dan bila nilai chi-square tabel > chisquare hitung, maka hipotesis ditolak. Sehingga, diperoleh hasil sebagai berikut:

a). Ada hubungan yang signifikan antara beban kerja dengan kelelahan kerja perawat RSIY PDHI.

b). Ada hubungan yang signifikan antara stres kerja dengan kelelahan kerja perawat RSIY PDHI.

c). Ada hubungan yang signifikan antara tingkat konflik dengan kelelahan kerja perawat RSIY PDHI.

\section{c. Pembahasan}

1). Hubungan antara Beban Kerja dengan Kelelahan Kerja Perawat

Beban kerja adalah lama seseorang melakukan aktivitas pekerjaan sesuai dengan kemampuan dan kapasitas kerja yang bersangkutan tanpa 
menunjukkan tanda kelelahan. Beban kerja erat kaitannya dengan kinerja, yang mana berkaitan pula dengan performanya. Apabila beban kerja berlebih akan berpengaruh dengan kinerjanya, dimana hal ini berkaitan dengan tingkat kelelahan seseorang.

Selama 2 bulan terakhir Rumah Sakit Islam Yogyakarta PDHI mengalami lonjakan pasien yang cukup signifikan. Hal ini disebabkan karena adanya perubahan cuaca yang menyebabkan peningkatan epidemiologi penyakit seperti fibris, ISPA, GEA (radang perut), TBC dan hipertensi. Sehingga menyebabkan meningkatnya pasien baik di rawat jalan maupun di rawat inap.

Jumlah tempat tidur yang masih terbatas di ruang rawat dewasa menyebabkan beberapa pasien yang harus dirawat inap sementara di titipkan ke ruang rawat anak. Sehingga, beban kerja perawat di ruang rawat anak menjadi berlebih.

Hal ini sesuai dengan penelitian yang menyatakan bahwa Semakin banyak tugas tambahan yang harus dikerjakan oleh seorang tenaga perawat maka akan menambah tingginya beban kerja demikian juga sebaliknya. Apabila hal ini masih dipertahankan, maka akan menyebabkan beban kerja yang berlebihan pada perawat. ${ }^{5}$

Apabila dilihat dari distribusi perawat sebagian besar perawat memiliki usia yang cukup produktif yakni berkisar antara 20 - 30 tahun. Pada usia produktif ini tentu perawat memiliki kinerja yang lebih optimal dibandingkan dengan yang telah berusia di atas itu.Hal I ni sesuai dengan pernyataan ${ }^{8}$ yang menyatakan bahwa karyawan muda umumnya mempunyai fisik yang lebih kuat, dinamis dan kreatif, sehingga dalam mengerjakan pekerjaan sehari - hari maka ia akan lebih mudah untuk mencapai kinerja secara maksimal. Demikian juga pernyataan ${ }^{9}$ bahwa, seorang karyawan muda yang memiliki sikap kreatif akan memiliki keinginan untuk maju, rasa ingin tahu yang tinggi, energik, terbuka menerima pendapat, memiliki inisiatif tinggi, serta pemikiran yang luas dan terarah yang menunjang pencapaian kinerja yang optimal.

Berdasarkan hasil analisis chi-square yang telah dilakukan, maka beban kerja mempunyai hubungan yang signifikan dengan kelelahan kerja. Hal ini karena nilai ñ value < á yakni $0,000>0,05$. Beban kerja yang tinggi dapat menyebabkan perawat mengalami kelelahan atau kejenuhan. Hal ini akan berdampak pada penurunan kualitas pelayanan keperawatan yang dilakukan oleh perawat.

Namun, hal ini berbeda dengan penelitian ${ }^{10}$ yang menyatakan tidak ada hubungan antara kelelahan dengan beban kerja $(\tilde{n}=0,199>0,05)$. faktor faktor yang berhubungan dengan beban kerja antara lain usia dan lama kerja.

Sedangkan, penelitian ini sejalan dengan penelitian yang mengatakan bahwa bekerja pada shift malam memiliki signifikansi kelelahan sebesar $\tilde{n}=$ 0,012, sehingga didapatkan beban kerja shift malam lebih tinggi dibandingkan shift pagi maupun siang, oleh karena itu dapat dikatakan beban kerja mempengaruhi kelelahan kerja ${ }^{11}$.

Beban kerja yang berlebihan dapat menyebabkan menurunnya moral dan motivasi perawat sehingga hal ini menjadi salah satu penyebab kelelahan kerja. Studi tentang faktor - faktor penyebab kelelahan kerja yang dilakukan pada beberapa ribu pria dan wanita dari ratusan perusahaan selama 20 tahun menunjukkan adanya 6 faktor yang berpengaruh dalam kelelahan, salah satunya adalah beban kerja yang berlebihan. 
Beban kerja perawat di Rumah Sakit Islam Yogyakarta PDHI adalah sedang dengan persentase $61,54 \%$. Apabila jumlah pasien semakin meningkat seiring dengan perubahan cuaca dan epidemiologi penyakit, maka akan semakin meningkatkan beban kerja perawat sehingga menyebabkan kelelahan kerja yang mempengaruhi performa kerjanya.

Untuk mengetahui tingkat keseimbangan antara beban kerja dan jumlah SDM, dapat dilakukan melalui penghitungan beban kerja dengan menggunakan rumusan normatif. Apabila hasil penghitungan menunjukkan ketidakseimbangan antara beban kerja dan jumlah SDM, maka upaya yang dapat dilakukan untuk mengatasi ketidakseimbangan tersebut adalah dengan pemberdayaan SDM (pendidikan/pelatihan, promosi, mutasi, demosi) dan rekrutmen perawat.

2). Hubungan antara Stres Kerja dengan Kelelahan Kerja Perawat

Stres merupakan ketidakmampuan mengatasi ancaman yang dihadapi oleh mental, fisik, emosional dan spiritual manusia yang pada suatu saat dapat mempengaruhi kesehatan fisik manusia tersebut. Stres adalah persepsi kita terhadap situasi atau kondisi di dalam lingkungan kita sendiri. Pengertian lain menyatakan bahwa stres merupakan suatu kondisi ketegangan yang mempengaruhi emosi, proses berpikir, dan kondisi seseorang. Jika seorang karyawan mengalami stres yang terlalu besar, maka akan mengganggu kemampuan seseorang tersebut untuk menghadapi lingkungan dan pekerjaannya. ${ }^{6}$

Meningkatnya tuntutan pekerjaan dan kebutuhan hidup akan sesuatu yang lebih baik, menyebabkan individu berlomba untuk memenuhi kebutuhan yang diinginkannya. Tapi pada kenyataannya sesuatu yang diinginkan tersebut kadangkala tidak dapat tercapai sehingga dapat menyebabkan individu tersebut bingung, melamun hingga stres. Stres yang terjadi pada setiap individu berbeda-beda tergantung pada masalah yang dihadapi dan kemampuan menyelesaikan masalah tersebut.

Meningkatnya tuntutan pekerjaan perawat saat naiknya lonjakan pasien di Rumah Sakit Islam Yogyakarta PDHI dapat menyebabkan stres kerja pada perawat, bila perawat tidak siap menghadapi perubahan yang pesat. Hasil tabulasi silang antara stres kerja dan kelelahan kerja perawat di RSIY PDHI menunjukkan bahwa tingkat stres perawat adalah sedang $(82,70 \%)$. Hal ini kemungkinan karena perawat sudah mempunyai pengalaman kerja yang cukup dan telah memahami epidemiologi penyakit yang muncul pada tahun tahun sebelumnya. Tetapi kemungkinan terjadinya stres kerja tetap ada, dikarenakan kondisi psikologis seseorang berbeda beda antara satu waktu dengan waktu yang lain. Stres kerja yang muncul di RSIY PDHI antara lain disebabkan karena beban kerja berlebih, perasaan cemas, dan suasana hati yang mudah berubah - ubah.

Berdasarkan hasil kuesioner penelitian didukung dengan wawancara kepada beberapa orang perawat, maka dapat diketahui bahwa stres kerja yang terjadi di Rumah Sakit Islam Yogyakarta PDHI antara lain disebabkan karena adanya faktor - faktor yang mempengaruhi terjadinya stres kerja, antara lain : 1). Kondisi pekerjaan, yang menyebabkan beban kerja berlebihan baik secara kuantitaif maupun kualitatif sehingga dapat meningkatkan ketegangan dan menyebabkan kelelahan mental dan atau fisik. Bila hal ini terus berkelanjutan dapat berubah menjadi kelelahan yang amat sangat dalam bekerja (burnout). 2). Faktor interpersonal, yang menyebabkan hasil kerja dan sistem dukungan sosial yang buruk, persaingan yang tidak sehat, dan kecemburuan sosial. 3). Tampilan rumah - 
pekerjaaan, yang dipengaruhi karena mencampuradukkan masalah pekerjaan dengan masalah pribadi, kurangnya dukungan dari pasangan hidup dan stres karena memiliki dua pekerjaan. Hal ini bila berkelanjutan akan memicu terjadinya konflik dan kelelahan secara mental.

penyebab stres kerja antara lain beban kerja yang dirasakan terlalu berat, waktu kerja yang mendesak, kualitas pengawasan kerja yang rendah, iklim kerja yang tidak sehat, autoritas kerja yang tidak memadai yang berhubungan dengan tanggung jawab, konflik kerja, perbedaan nilai antar karyawan dengan pimpinan yang frustasi dalam kerja. Pendapat ini sejalan dengan ${ }^{12}$ yang menyatakan penyebab timbulnya stres kerja dikarenakan suatu tuntutan pekerjaan yang di luar batas kemampuan individu.

Studi kepustakaan tentang stres menunjukkan bahwa wanita rentan terkena stres. Berdasarkan fakta historis dan perbedaan peranan yang sejak dulu ada antara pria dan wanita, sekarang terdapat tanda - tanda bahwa peranan pria dan wanita secara perlahan - lahan telah berubah. Semakin lama semakin banyak wanita yang memasuki kehidupan organisasi, karena itu wanita sekarang menjadi lebih rentan terkena stres.

Berdasarkan hasil analisis chi-square yang telah dilakukan, maka dapat disimpulkan bahwa stres kerja mempunyai hubungan yang signifikan dengan kelelahan kerja. Hal ini karena nilai ñ value < á yakni $0,026<0,05$. Hal ini berarti stres kerja mempunyai hubungan yang signifikan dengan kelelahan kerja.

Penelitian ini sesuai dengan hasil penelitian yang menyatakan bahwa hubungan antara variabel stres kerja dan kinerja mempunyai koefisien korelasi sebesar $-0,459$. Hal ini menunjukkan korelasi yang cukup kuat antara stres kerja dan kinerja. Arah hubungan negatif menunjukkan semakin besar stres kerja akan membuat kinerja menurun dan mengakibatkan kelelahan otot. Demikian pula pada penelitian ini, perawat dengan stres kerja yang tinggi akan semakin meningkatkan kelelahan kerja pada perawat. ${ }^{7}$

Hasil penelitian ini juga sejalan dengan yang dikemukakan ${ }^{13}$ yang menyebutkan bahwa terjadinya kelelahan kerja diakibatkan oleh stress kerja. Selye ${ }^{12}$ mengungkapkan bahwa eustress yaitu stres yang merupakan kekuatan yang positif yang diperlukan bagi seseorang guna menghasilkan prestasi yang tinggi. Jadi untuk menghasilkan prestasi yang tinggi dibutuhkan tingkat stres kerja yang rendah dan untuk menghasilkan stres yang rendah diperlukan pemahaman persepsi positif mengenai kelelahan kerja dari pekerjaan yang ditanganinya.

Stres kerja dalam jumlah tertentu dapat mengarah ke gagasangagasan yang inovatif dan keluaran yang konstruktif. Sampai titik tertentu bekerja dengan tekanan batas waktu dapat merupakan proses kreatif yang merangsang seseorang. Seorang yang bekerja pada tingkat optimal menunjukkan antusiasme, semangat yang tinggi, kejelasan dalam berfikir dan pertimbangan atau perhitungan yang cermat. Penelitian lain mempertegas bahwa bila tidak ada stres kerja maka tantangan-tantangan kerja juga tidak ada sehingga prestasi kerja cenderung menurun ${ }^{10}$. Tetapi bila stres kerja terlalu besar maka prestasi kerja juga akan menurun karena stres kerja dapat mengganggu pelaksanaan pekerjaan yang dihadapinya. ${ }^{6}$

Oleh karena itu, faktor - faktor yang mempengaruhi stres kerja perawat seperti emosi, pikiran, perasaan, situasi kerja dan tuntutan pekerjaan perlu dikendalikan untuk meminimalisir terjadinya stres kerja. Namun, perlu diingat pula, bahwa stres kerja juga diperlukan untuk mendorong dan memotivasi perawat dalam bekerja. 
Hasil penelitian ini didapatkan stres kerja perawat sedang dengan persentase $82,70 \%$. Perawat dengan tingkat stres yang sedang rata-rata masih dapat menyelesaikan pekerjaannya. Hal ini didukung dengan adanya pelatihan building skill yang diselenggarakan oleh pihak rumah sakit untuk meningkatkan kemampuan kerja perawat.

3). Hubungan antara Tingkat Konflik dengan Kelelahan Kerja Perawat

Konflik merupakan pertentangan antara dua atau lebih terhadap satu hal atau lebih dengan sesama anggota orgaisasi atau dengan organisasi lain. Konflik dapat terjadi karena persaingan yang tidak sehat diantara rekan kerja, namun dapat juga menimulkan dinamika kerja, sehingga pencapaian kerja menjadi lebih baik.

Konflik yang terjadi di Rumah Sakit Islam Yogyakarta PDHI antara lain karena adanya perbedaan persepsi, perbedaan cara merealisasikan tujuan, persaingan yang kurang sehat di antara perawat, adanya permasalahan pribadi yang terbawa saat bekerja dan perasaan sedih saat bertengkar dengan sesama perawat. Dua konflik yang pertama merupakan jenis konflik yang apabila dikelola dengan baik maka akan meningkatkan efektifitas organisasi dan meminimalisir terjadinya kelelahan kerja perawat. Konflik konflik yang lainnya rata - rata masih dapat segera diatasi oleh Kepala Ruang di masing - masing bangsal rawat inap. Sehingga dapat dikatakan bahwa tingkat konflik yang terjadi pada perawat rawat inap di Rumah Sakit Islam Yogyakarta PDHI adalah optimal. Namun, tetap perlu dilakukan pengelolaan yang baik agar konflik tidak meningkat, karena apabila dilihat dari tabel distribusi tingkat konflik, maka perawat dengan tingkat konflik tinggi lebih banyak dibandingkan dengan perawat dengan tingkat konflik yang rendah. Sehingga, tetap ada potensi tingkat konflik akan naik apabila faktor pemicu konflik meningkat.

Berdasarkan hasil analisis chi-square yang telah dilakukan, maka dapat disimpulkan bahwa tingkat konflik mempunyai hubungan yang signifikan dengan kelelahan kerja. Hal ini karena nilai ñ value < á yakni 0,000<0,05. Konflik merupakan hasil dari ketidakkonsistenan harapan - harapan berbagai pihak atau persepsi adanya ketidakcocokan antara tuntutan peran dengan kebutuhan. Sebagai akibatnya seseorang yang mengalami konflik peran akan berada dalam suasana yang terombang - ambing, terjepit dan serba salah. Seperti halnya perawat yang seharusnya jaga sore, tetapi harus datang pagi karena mendapat on call dari rekannya yang bertugas jaga pagi yang kewalahan dengan menumpuknya pasien di pagi hari. Seharusnya waktu tersebut dapat menjadi waktu istirahatnya, namun karena panggilan tugas, maka ia harus selalu siap. Sistem on call ini telah dilakukan di bangsal Halimah yang merupakan bangsal obsgyn di Rumah Sakit Islam Yogyakarta PDHI ini.

Pada hakekatnya, terdapat dua pandangan utama dalam memandang konflik, yaitu pandangan tradisional dan interaksional. Dalam pandangan tradisional, konflik dianggap mengganggu kerjasama untuk mencapai tujuan organisasi. Sehingga dalam konsep pemikiran tersebut, konflik selalu mengandung pengertian negatif, jelek dan destruktif. Tanggungjawab manajemen adalah mencegah timbulnya konflik sampai ke akar - akarnya. Sebaliknya, dalam pandangan interaksional, konflik justru mendorong terjadinya efektivitas organisasi, dalam bentuk perubahan dan pengambilan keputusan yang lebih baik. Tanpa konflik, suatu organisasi akan statis, apatis dan tidak responsif. Namun, agar konflik dapat fungsional maka harus dikendalikan secara cerdas dan profesional, sehingga efektivitas organisasi akan optimal. 
Dari hasil penelitian diperoleh bahwa tingkat konflik responden adalah sedang dengan persentase $67,30 \%$. Apabila konflik yang ada dikelola dengan baik, maka akan menghasilkan efektifitas organisasi yang tinggi dan meningkatkan semangat kerja sehingga kelelahan kerja akibat konflik kerja dapat diminimalisir.

\section{SIMPULAN DAN SARAN}

\section{a. Simpulan}

Berdasarkan hasil penelitian dan pembahasan, maka dapat ditarik kesimpulan sebagai berikut:

1). Ada hubungan yang signifikan antara beban kerja dengan kelelahan kerja perawat di Rumah Sakit Islam Yogyakarta PDHI dengan nilai taraf signifikansi $0,000<0,05$.

2). Ada hubungan yang signifikan antara stres kerja dengan kelelahan kerja perawat di Rumah Sakit Islam Yogyakarta PDHI dengan nilai taraf signifikansi 0,026 < 0,05 .

3). Ada hubungan yang signifikan antara tingkat konflik dengan kelelahan kerja perawat di Rumah Sakit Islam Yogyakarta PDHI dengan nilai taraf signifikansi $0,000<0,05$.

\section{b. Saran}

1). Bagi Pihak Rumah Sakit Islam Yogyakarta PDHI

a). Perlunya dibuat suatu kebijakan terkait dengan pengembangan karir perawat yang berdasarkan kompetensi dan kinerja agar mereka tetap termotivasi dalam bekerja walaupun dengan beban kerja yang tinggi.

b). Perlu strategi pengelolaan stres pada perawat untuk meminimalisir kelelahan kerja akibat stres kerja, seperti dilakukan pertukaran shift kerja, kegiatan di luar kerja dan juga outbond.

c). Perlu mengoptimalkan konflik dengan mendinamiskan iklim kerja yang sehat.

2). Bagi Kepala Keperawatan Rumah Sakit Islam Yogyakarta PDHI

Perlu mempertimbangkan penambahan jumlah perawat mengingat jumlah perawat yang masih kurang dibandingkan dengan kebutuhan pasien yang semakin meningkat.

3). Bagi Peneliti Selanjutnya

Perlu dilakukan penelitian lebih lanjut mengenai rasio beban kerja perawat dan juga penghitungan tenaga kerja perawat dikaitkan dengan kelelahan kerja perawat.

\section{DAFTAR PUSTAKA}

1. Nursalam. Manajemen Keperawatan Aplikasi dalam Praktik Keperawatan Profesional, Edisi Pertama. Salemba Medika, Jakarta. 2002

2. Notoatmodjo, S. Prinsip - Prinsip Dasar IImu Kesehatan Masyarakat, Cetakan Kedua, Rineka Cipta, Jakarta. 2003

3. Sugiyono.Metode Penelitian Bisnis, Alfabeta, Bandung. 2003

4. Sujarweni. Belajar Mudah SPSS untuk penelitian skripsi, tesis, disertasi dan umum, Global Media Informasi, Jakarta. 2008

5. Irwandy.Faktor-Faktor yang Berhubungan dengan Beban Kerja:http:// www.liwandy.kapalawi.wordpress.com, diambil tanggal 8 Juni 2009. 2007

6. Handoko. Manajemen Personalia dan Sumber Daya Manusia, Edisi 2, BPFE, Yogyakarta. 1992 
7. Iswanto. Analisis Hubungan Antara Stres Kerja, Kepribadian, Dan Kinerja Manajer Bank, Skripsi, Universitas Terbuka, Jakarta. 2001

8. Hasibuan.Manajemen SDM, Dasar dan Kunci Keberhasilan.jakarta :CV.Haji Masagung.2005

9. Mangkunegara.Manajemen SDM Perusahaan.Bandung:Rosdakarya.2001

10. Dewi.Beberapa Faktor yang Berhubungan dengan Kelelahan pada Perawat di Rumah Sakit Adi Husada Vandaan,Wetan Kota Surabaya. Tesis Fakultas Kesehatan Masyarakat Universitas Airlangga Surabaya.2009

11. Windiati.Perbedaan Kelelahan Perawat berdasarkan shift Keja (studi di Instalasi Rawat Inap RSD Dr. H.Koesnadi Bondowoso).Tesis Fakultas Kesehatan Masyarakat Universitas Airlangga Surabaya.2006

12. Widyasari,P. Http:Ilwww.rumah-belajar-psikologi/stress kerja.stress kerja.diambil tanggal 20 mei 2009.

13. Tarwaha,dkk.2004.ergonomi untuk keselamatan,kesehatan kerja dan produktivitas.surakarta:UNIBA Press. 